\title{
Augmentacja kości z wykorzystaniem mezenchymalnych komórek macierzystych - przegląd piśmiennictwa
}

\author{
Bone augmentation through use of mesenchymal stem cells - a literature review \\ ${ }^{1}$ Klinika Gerostomatologii, Uniwersytet Medyczny im. Karola Marcinkowskiego w Poznaniu \\ ${ }^{2}$ Zakład Biologii Rozrodu i Komórek Macierzystych, Instytut Genetyki Człowieka Polskiej Akademii Nauk, Poznań
}

DOI: http://dx.doi.org/10.20883/df.2017.12

\begin{abstract}
Streszczenie
Powszechne występowanie i łatwa dostępność mezenchymalnych komórek macierzystych w tkankach zębowych sprawiają, że istnieje realna szansa ich zastosowania w celach terapeutycznych z jednoczesnym rozwiązaniem konfliktów natury etycznej. Odbudowa struktury tkanki kostnej oraz przywrócenie jej funkcji podporowej i odżywczej z wykorzystaniem mezenchymalnych komórek macierzystych stwarza niebywałą szansę osiągnięcia spektakularnych efektów u pacjentów, u których dotychczas stosowane rutynowe postępowanie nie dawało satysfakcjonujących rezultatów.
\end{abstract}

Słowa kluczowe: augmentacja kości, mezenchymalne komórki macierzyste, implanty stomatologiczne.

\begin{abstract}
Mesenchymal stem cells are abundant and easily accessible in dental tissues, so there is a real opportunity to use them for therapeutic purposes. Their use is also ethically non-controversial. Bone tissue structure augmentation, together with restoring its weight-bearing and nutritive function, based on using mesenchymal stem cells provides anexcellent opportunity to obtain spectacular results in patients in whom routine treatments did not lead to satisfactory results.
\end{abstract}

Keywords: bone augmentation, mesenchymal stem cells, dental implants.

\section{Wprowadzenie}

Regeneracja kości to złożony, fizjologiczny proces biologiczny tworzenia się nowej tkanki kostnej, obserwowany w czasie jej gojenia, podlegający ciągłym zmianom w trakcie całego dorosłego życia. Zabiegi chirurgiczne w obrębie twarzoczaszki, polegające na zachowaniu lub odbudowie utraconej masy kostnej, służą stworzeniu właściwych warunków dla wprowadzenia implantów śródkostnych. W ostatnim czasie dokonał się postęp w technikach umożliwiających odbudowę i regenerację utraconej tkanki kostnej, tym samym możliwe stało się uzyskanie satysfakcjonujących pod względem estetycznym i funkcjonalnym wyników leczenia stomatologicznego.

\section{Komórki macierzyste}

Zabiegi w obrębie jamy ustnej, mające na celu regenerację kości wyrostka zębodołowego, mogą przebiegać z wykorzystaniem przeszczepów autogennych zawierających żywe komórki lub wszczepiennych, kościozastępczych materiałów allogennych, ksenogennych lub alloplastycznych, które pozbawione są żywych komórek. Mechanizmy osteoindukcji i osteokondukcji oraz właściwości osteogenne regulują potencjał regeneracyjny tych materiałów (Rycina 1).
Zwiększenie przestrzennych wymiarów zanikłego wyrostka zębodołowego, szczególnie dużych, pionowych ubytków, z zastosowaniem klasycznych metod augmentacyjnych nie jest jednak łatwe. Materiały kościozastępcze stosowane w leczeniu implantoprotetycznym nie posiadają właściwości osteogennych. Ich wprowadzenie do organizmu uruchamia nieuniknione zjawiska resorpcji i rozpuszczania kości, poprzez aktywację osteoklastów, jako odpowiedź układu immunologicznego przeciwko materiałom wszczepiennym.

Autogenna kość gąbczasta jako jedyna posiada właściwości zarówno osteokondukcyjne, osteoindukcyjne, jak i osteogenne. Jej użycie stanowi do dzisiaj złoty standard w leczeniu odtwórczym. Autografty są najbardziej skuteczne pod względem biologicznym i klinicznym, zawierają żywe komórki kostne, które gwarantują biokompatybilność i nie oddziałują negatywnie na układ immunologiczny organizmu biorcy. W rekonstruowanym obszarze zintegrowaną i unaczynioną kość, przygotowaną do przeprowadzenia dalszych zabiegów z zakresu implantoprotetyki, otrzymuje się w okresie od czterech do dwunastu miesięcy.

Pobranie i wykonanie przeszczepu wiąże się z koniecznością przeprowadzenia dodatkowego 


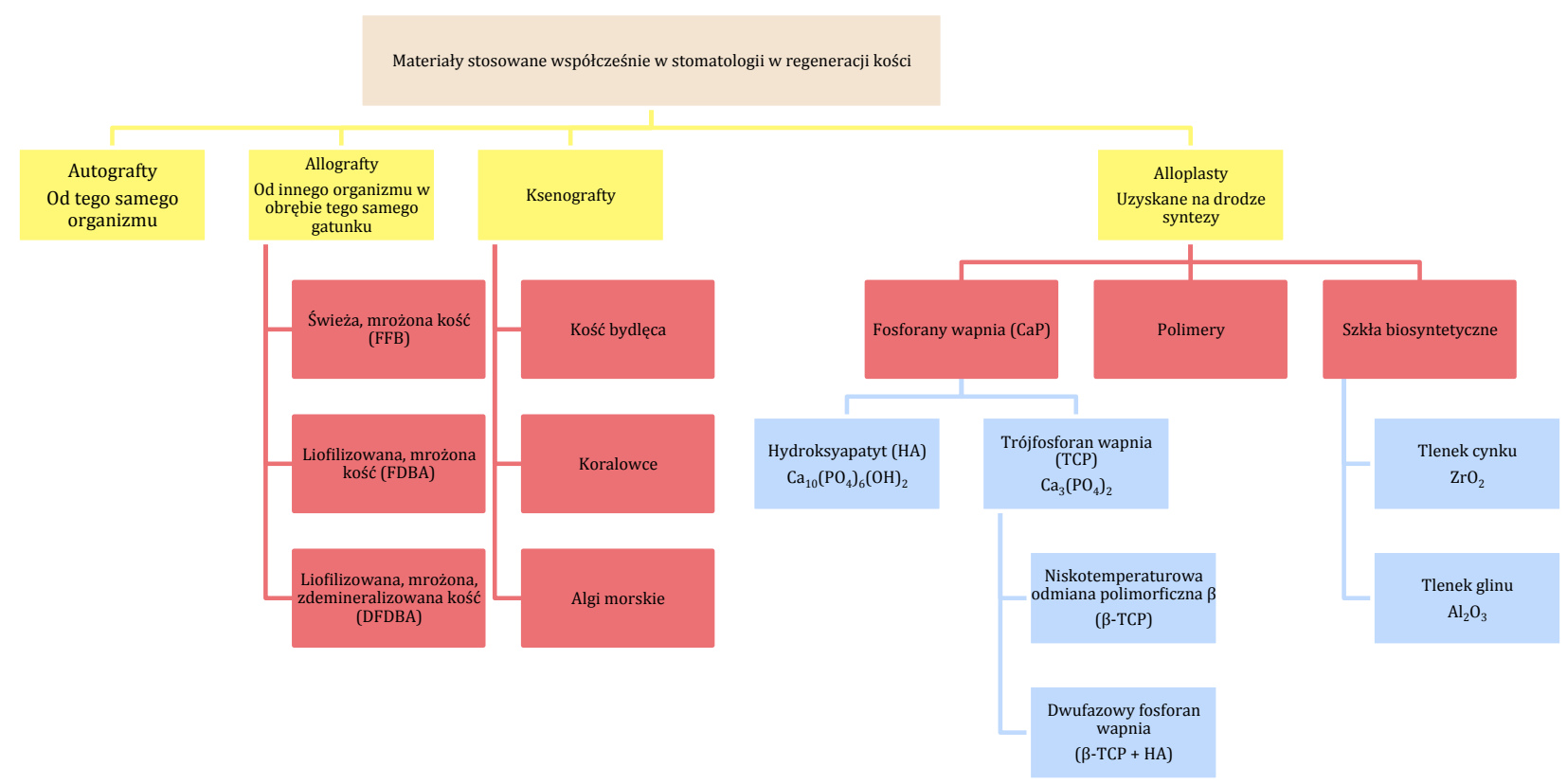

Rycina 1. Materiały stosowane współcześnie w augmentacji kości w stomatologii

Figure 1. The materials currently used in bone augmentation in dentistry

zabiegu chirurgicznego, osłabieniem kości w miejscu pobrania oraz zwiększonym ryzykiem wystąpienia powikłań i dolegliwości pozabiegowych. llość materiału potrzebnego do przeszczepu jest często ograniczona, a potencjał regeneracyjny autograftów może różnić się w zależności od osoby i miejsca pobrania.

Powyższe wady związane ze stosowaniem przeszczepów kostnych sprawiły, że nieustannie szuka się nowych rozwiązań z zakresu inżynierii tkankowej, także tych z wykorzystaniem komórek macierzystych, które w sposób przewidywalny, długoczasowy pozwalą odbudować brakującą kość wyrostków zębodołowych. Uważa się, że realizacja współczesnych kryteriów powodzenia leczenia implantologicznego (pełna integracja wszczepu z kością, zanik kości brzeżnej wokół implantu poniżej $0,2 \mathrm{~mm}$ oraz funkcjonowanie opartego na implantowanym filarze uzupełnienia protetycznego) w perspektywie wieloletniej, będzie możliwa tylko dzięki zastosowaniu mezenchymalnych komórek macierzystych (ang. mesenchymal stem cells, MSC) [1].

\section{Kliniczne wykorzystanie komórek macierzystych}

Obecność komórek macierzystych wykazano w wielu tkankach i narządach organizmu ludzkiego, takich jak szpik kostny, siatkówka i skóra. Źródłem komórek macierzystych mogą być także tkanki układu stomatognatycznego, w tym jamy ustnej i zębów (Rycina 2). Ich występowanie w tkankach całego organizmu sprawia, że w po- równaniu z innymi typami komórek macierzystych istnieje realna szansa ich klinicznego wykorzystania w celach terapeutycznych. Użycie dojrzałych komórek macierzystych nie jest tak kontrowersyjne jak w przypadku komórek embrionalnych, ponieważ zastosowanie komórek somatycznych nie wymaga zniszczenia embrionu.

Komórki macierzyste mogą skutecznie poprawiać regeneracyjne możliwości technik augmentacyjnych w dwojaki sposób. Po pierwsze mogą posłużyć do laboratoryjnego przygotowania preparatu sztucznego z wykorzystaniem materiałów kostnych lub wszczepiennych, który mógłby być także potencjalnie dostępny komercyjnie na rynku. $Z$ drugiej strony komórki te mogą być użyte w celu przygotowania preparatu świeżego na miejscu na sali zabiegowej, przeznaczonego do bezpośredniego zastosowania.

W 2003 roku po raz pierwszy wykorzystano komórki macierzyste wraz z przeszczepem kostnym w celu augmentacji kości w przednim odcinku szczęki [2]. Rok później ta sama grupa naukowców zaobserwowała formowanie się kości beleczkowej trzy miesiące po przeszczepie w badaniu klinicznym, przeprowadzonym na grupie 27 pacjentów [3]. W 2004 roku Ueda i wsp. wykorzystali mieszaninę komórek macierzystych pobranych ze szpiku kostnego (ang. bone marrow stem cells, BMSC) oraz autogennego osocza bogatopłytkowego (ang. platelet-rich plasma, PRP), którą wprowadzili do organizmu w trakcie implantacji [4]. Tą samą metodą posłużyli się w leczeniu zapalenia przyzębia [5], w trakcie augmentacji kości 


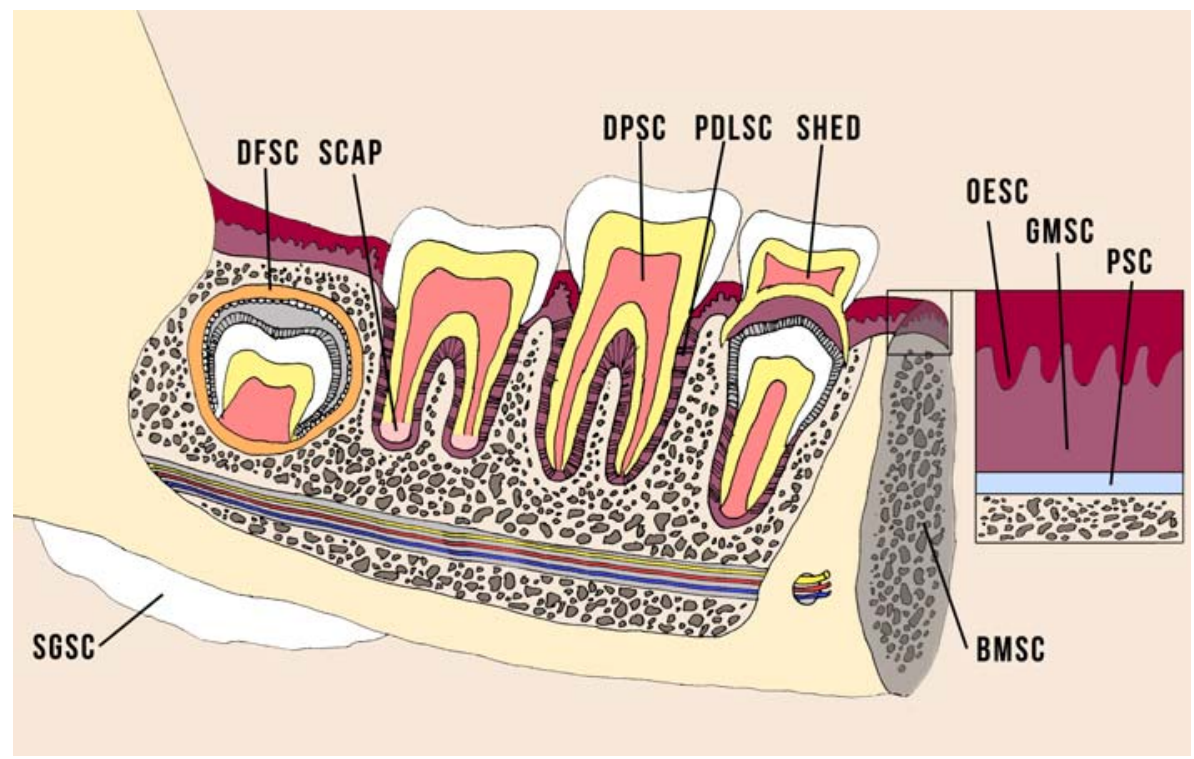

Rycina 2. Źródła komórek macierzystych zlokalizowane w obrębie jamy ustnej: BMSC (komórki macierzyste szpiku kostnego); DPSC (komórki macierzyste miazgi zębów); SHED (komórki macierzyste zębów mlecznych); PDLSC (komórki macierzyste więzadła ozębnowego); SCAP (komórki macierzyste brodawki wierzchołkowej); DFSC (komórki macierzyste woreczka zębowego); GMSC (komórki macierzyste dziąsła); OMSC (komórki macierzyste błony śluzowej jamy ustnej); PSC (komórki macierzyste okostnej); SGSC (komórki macierzyste gruczołów ślinowych) (ze zbiorów własnych)

Figure 2. Sources of stem cells located in the oral cavity: BMSC (bone marrow-derived mesenchymal stem/stromal cells); DPSC (dental pulp stem cells); SHED (stem cells from human exfoliated decidous teeth); PDLSC (periodontal ligament stem cells); SCAP (stem cells of the apical papilla); DFSC (dental follicule stem cells); GMSC (gingiva-derived mesenchymal stem cells); OMSC (oral mucosa stem cells); PSC (periosteum-derived stem/progenitor cells); SGSC (salivary gland-derived stem cell) (from private collection)

oraz wykonując zabieg podniesienia dna zatoki szczękowej. Skuteczność komórek macierzystych pobranych ze szpiku kostnego w regeneracji zanikłej kości w obrębie jamy ustnej oraz posiadanie doskonałych właściwości osteogennych zostały także potwierdzone w badaniach, w których BMSC zastosowano razem $z$ hydroksyapatytem (HA) [6], HA i jedną z polimorficznych odmian trójfosforanu wapnia (ang. tricalcium phosphate, TCP), żelową gąbką, HA/TCP oraz mrożoną kością gąbczastą. W regeneracji kości oraz leczeniu implantoprotetycznym użyteczne mogą być także komórki macierzyste pochodzące $z$ tkanki tłuszczowej oraz komórki macierzyste pochodzące z miazgi zęba [7].

Doniesienia dotyczące stosowania komórek macierzystych w praktyce klinicznej wydają się być optymistyczne. Opisywane w piśmiennictwie światowym wątpliwości dotyczą braku dokładnej charakterystyki przeszczepianych komórek oraz braku ustalonego, optymalnego protokołu izolacji i ekspansji komórek macierzystych, który pozwalałby na uzyskanie w sposób przewidywalny populacji komórek przeznaczonych do przeszczepu. Meijer i wsp. opisali dużą zmienność międzyosobniczą w tworzeniu kości u pacjentów leczonych z zastosowaniem komórek macierzystych [6]. Przeprowadzone przez Kaigler i wsp. badania w schemacie RCT (ang. randomized controlled trial) wykazały, że terapia z wykorzystaniem komórek macierzystych izolowanych ze szpiku kostnego i wzbogaconych o populację komórek charakteryzujących się obecnością antygenów powierzchniowych CD90 i CD15 przyspiesza regenerację kości wyrostków zębodołowych w porównaniu z techniką sterowanej regeneracji kości [8].

Istnieje konieczność prowadzenia dalszych randomizowanych badań klinicznych w celu ustalenia, czy nowoczesne techniki z zakresu inżynierii tkankowej przynoszą długoczasowe, pożądane dla pacjentów efekty terapeutyczne. Do tej pory nie opracowano także schematów postępowań, dotyczących optymalnego przygotowania przeszczepianych komórek oraz doboru nośnika, zapewniającego swobodną migrację komórek, łatwy dostęp do składników odżywczych i czynników wzrostu oraz odpowiednie odprowadzanie produktów ubocznych.

W 2006 roku Smiler i Soltan po raz pierwszy opisali technikę wykorzystującą pobrane z talerza 
kości biodrowej świeże komórki macierzyste oraz bloki kostne stanowiące rusztowanie dla tworzącej się nowej kości. Wykazano, że metoda ta skutecznie regeneruje kość, a w przyszłości, w opinii autorów, może zastąpić złoty i stać się platynowym standardem w leczeniu odtwórczym. Metoda wykorzystana w wyżej wspomnianych badaniach została już wcześniej dobrze udokumentowana w piśmiennictwie. Polega na wytworzeniu w specjalnej wirówce skoncentrowanego preparatu o małej objętości, zawierającego kilkukrotnie większą ilość komórek macierzystych niż bazowy szpik. Koncentrat zawierający frakcję komórek jednojądrzastych szpiku kostnego (ang. bone marrow aspirate concentrate, BMAC), podany w docelowym, przeznaczonym do regeneracji miejscu, wspomaga i przyspiesza gojenie, stymuluje wzrost komórek osteogennych i tkanki kostnej oraz tworzenie naczyń krwionośnych [9].

Wykazano, że koncentrat frakcji jednojądrzastych komórek macierzystych w połączeniu ze świeżą kością mrożoną (ang. fresh frozen bone, FFB) są źródłem powstawania drobnowłóknistej kości blaszkowatej. Utworzona przez kość gąbczastą i zbitą, składa się z gęsto utkanych, równolegle ułożonych włókien kolagenowych. Jest wysoko zmineralizowana, a tym samym zdolna do przenoszenia dużych obciążeń, na przykład poprzez implantowane w jej obrębie filary dentystyczne.

Randomizowane, prospektywne badania kliniczne Rickerta i wsp. dotyczące pacjentów, u których przeprowadzono obustronnie zabieg podniesienia dna zatoki szczękowej, wykazały, że koncentrat bogatokomórkowy w połączeniu z FFB charakteryzuje się wyższym potencjałem osteogennym w porównaniu z przeszczepem autologicznym kości. Badania histomorfometryczne, pozwalające ilościowo opisać jakość tkanki kostnej, potwierdziły, że po stronie, w której implantowane zostały komórki macierzyste, uzyskano relatywnie więcej kości niż w zatoce przeciwległej, gdzie wszczepiony został jedynie preparat autograficzny [10]. W randomizowanych, kontrolowanych badaniach histologicznych oraz klinicznych, prowadzonych z udziałem pacjentów metodą pojedynczej ślepej próby wykazano, że w okresie 3-4 miesięcy po przeprowadzeniu zabiegu podniesienia dna zatoki szczękowej użycie koncentratu komórek macierzystych nie wpłynęło na zwiększenie ilości odkładanej kości w rejonie augmentowanym. Zastosowanie BMAC w połączeniu z materiałem FFB należy traktować jako alternatywę dla materiałów autogennych [11].

Komórki macierzyste przeszczepione natychmiast po pobraniu aspiratu nie wywołują objawów klinicznych ani zmian histologicznych w komór- kach, będących mediatorami odczynu zapalnego. W piśmiennictwie podkreślane jest także terapeutyczne, przeciwzapalne działanie komórek macierzystych szpiku kostnego i podanych miejscowo lub drogą dożylną. Preparat świeży, podany do organizmu biorcy, nie jest jednorodny, w swym składzie może zawierać komórki różnego typu: komórki macierzyste, osteogenne komórki prekursorowe, komórki hematopoetyczne szpiku, komórki przyspieszające tworzenie naczyń krwionośnych oraz komórki zrębu.

\section{Kierunki prowadzonych prac badawczych}

Terapia wykorzystująca komórki macierzyste w regeneracji kości wydaje się być obiecująca. Jest to jednak nowa dyscyplina inżynierii tkankowej, mechanizmy zachodzące $\mathrm{w}$ organizmie podczas transplantacji nie są do końca poznane. W ocenie klinicznej przydatności komórek macierzystych nie jest jasne, czy nowa kość odkładana jest przez przeszczepione komórki macierzyste (rola osteogenna komórek macierzystych) czy może przez komórki kościotwórcze gospodarza, które stymulowane są transplantowanymi komórkami macierzystymi (rola osteoindukcyjna komórek macierzystych) [12]. Budowa morfologiczna MSC jest dokładnie poznana, brakuje wyjaśnień opisujących właściwości biologiczne komórek macierzystych, szczególnie w środowisku po ich wprowadzeniu do organizmu biorcy. Hodowla i ekspansja MSC mogą dodatkowo zmieniać ich podstawowe właściwości biologiczne, mało znany jest także ich wpływ na układ immunologiczny gospodarza.

\section{Wskaźnik przeżycia transplantowanych komórek}

Obecność komórek macierzystych, użytych $w$ technikach regeneracyjnych kości, jest nieodzowna przynajmniej do czasu wytworzenia sieci kapilarnych naczyń krwionośnych, które zaopatrują przeszczep w tlen i substancje odżywcze oraz usuwają zbędne produkty przemiany materii.

W licznych badaniach wykazano krótki okres przeżycia komórek macierzystych, umieszczonych w ubytkach kostnych. Zimmermann i wsp. po oznaczeniu MSC barwnikiem fluorescencyjnym, umieszczeniu na rusztowaniu wykonanym z mieszanki hydroksyapatytu i fosforanu $\beta$-trójwapniowego oraz wszczepieniu ich podskórnie izogenicznym szczurom stwierdzili, że transplantowane komórki nie występowały w przeszczepie już w 14 dniu po zabiegu [13].

Wyniki obserwacji zostały potwierdzone w podobnych badaniach, przeprowadzonych przez Boukhechba i wsp. [14] - komórki MSC nie przetrwały dłużej niż 3 tygodnie po przeszczepie. Quintavalla 
i wsp. zmniejszenie liczby przeszczepionych komórek zaobserwowali już w 7 dniu trwania eksperymentu [15].

W licznych badaniach przeprowadzonych na ludziach [16-18] i zwierzętach [19-21] wykazano, że zastosowanie komórek macierzystych znacząco przyspiesza procesy osteogenezy. Gdyby jednak transplantowane komórki były źródłem osteoblastów, odpowiedzialnych za tworzenie nowej kości, musiałyby przetrwać odpowiednio długi czas, potrzebny na uruchomienie procesów związanych z produkcją macierzy kostnej i jej późniejszą mineralizacją.

Można zatem przypuszczać, że transplantowane komórki macierzyste nie są wyłącznie źródłem osteoblastów odpowiedzialnych za formowanie kości, ale mogą też pobudzać organizm gospodarza do rekrutacji endogennych komórek odpowiedzialnych za procesy kościotworzenia, mogą pełnić także funkcję immunomodulacyjne.

Formowanie sieci kapilarnych naczyń krwionośnych jest niezbędne w procesie tworzenia nowej kości. Sieć ta dostarcza na miejsca docelowe tlen i składniki odżywcze oraz odbiera produkty przemiany materii, umożliwia także dotarcie komórek progenitorowych, koniecznych w procesie osteogenezy. Bardzo obiecującą i szeroko badaną w ostatnich czasach techniką wspomagania angiogenezy jest przeszczepienie w wybrane miejsce prekursorów komórek śródbłonka (ang. endotelialial progenitor cell, EPC). Komórki te w miejscu docelowym różnicują się w komórki śródbłonkowe, znacząco przyspieszając proces tworzenia naczyń. Obiecujące efekty otrzymano przy zastosowaniu tej metody w eliminacji skutków zawału serca w zwierzęcym modelu doświadczalnym [22].

\section{Rekrutacja endogennych komórek osteoprogenitorowyh}

Choć organizm ludzki, w tym także jama ustna, może stanowić doskonałe źródło komórek macierzystych, strategie wykorzystujące te komórki w regeneracji kości nie zawsze wykazują pożądaną skuteczność. Poszukuje się rozwiązań alternatywnych, między innymi z wykorzystaniem komórek pochodzenia endogennego.

Chemokiny to białka z grupy cytokin, wykazujące aktywność chemotaktyczną. Nadają one zdolność komórkom posiadającym odpowiednie receptory do migracji zgodnie z gradientem chemokinowym [23]. Obecnie znanych jest okoto 50 chemokin i 20 receptorów chemokinowych. Ze względu na lokalizację dwóch reszt cysteiny w N-końcowym fragmencie cząsteczki, chemokiny dzieli się na 4 klasy: CC, CXC, CX3C i C. Analogiczna nomenklatura dotyczy receptorów chemokinowych. Udowodniono, że chemokinowe szlaki sygnałowe SDF-1 (CXCL12)/CXC4 oraz MCP-1 (CCL2)-CCR2 są kluczowe w mobilizacji, proliferacji oraz przeżyciu wielu typów komórek, w tym także osteoprogenitorowych komórek macierzystych.

Czynnik pochodzenia stromalnego 1 (ang. stromal cell-derived factor-1, SDF-1), wyodrębniony w 1993 roku, znany jest także jako chemokinowy ligand 12 należący do klasy CXC (ang. CXC ligand 12, CXCL12) [24]. Jest jedynym ligandem receptora CXCR4, ale SDF-1 jest także zdolne łączyć się z receptorem CXCR7. Oba receptory należą do receptorów sprzężonych z białkiem $\mathrm{G}$ (ang. G protein-coupled receptor, GPCR). Przekazywanie sygnału przez układ dwóch białek SDF-1 (ligand)/CXCR4 (receptor) jest procesem niezwykle złożonym i delikatnym, aktywuje szereg ścieżek sygnałowych w komórkach docelowych. Oś SDF-1/CXC4 odgrywa główną rolę w prawidłowej migracji, zasiedlaniu, odnowie (tzw. repopulacji), różnicowaniu oraz przeżyciu wielu typów komórek progenitorowych. Ma podstawowe znaczenie w migracji komórek macierzystych pomiędzy szpikiem kostnym a krwią. Ponadto w wyniku uszkodzenia tkanki dochodzi do lokalnego wzrostu poziomu SDF-1. Na drodze zależnej od SDF-1 przeszczepione komórki macierzyste są mobilizowane do uszkodzonej tkanki, gdzie mogą uczestniczyć w jej rekonstrukcji.

Głównym źródłem SDF-1 w dorosłych organizmach są komórki zrębu, śródbłonka i siateczki, zlokalizowane w obrębie okołonaczyniowej niszy szpiku kostnego. Zwiększoną ekspresję SDF-1 obserwuje się także w osteoblastycznych komórkach progenitorowych, w przeciwieństwie do krwiotwórczych komórek macierzystych szpiku kostnego. Swoisty dla tego ligandu receptor CXCR4 ulega zaś ekspresji w komórkach hematopoetycznych, osteoblastach oraz w mezenchymalnych komórkach macierzystych. Stężenie cytokiny SDF-1 zwiększa się w miejscu urazu, stymuluje chemotaksję endogennych komórek progenitorowych CXCR4+, które są nieodzowne w procesach naprawy i regeneracji wielu narządów, w tym także tkanki kostnej.

Chemokina prozapalna MCP-1 (ang. monocyte chemotactic protein-1), znana również jako CCL2 (ang. $C-C$ chemokine ligand type 2), jest białkiem wykazującym aktywność chemotaktyczną dla monocytów oraz bazofili. Głównym zadaniem CCL2 jest aktywowanie leukocytów do chemotaksji, co stanowi kluczowy etap rozwoju odpowiedzi immunologicznej. Chemokinowy receptor CCR2, znany też jako CD192, związany jest z białkiem G, transmembranowym receptorem, uczestniczącym 
w transdukcji sygnałów zewnątrzkomórkowych (związanie liganda) na sygnał wewnątrzkomórkowy (aktywacja białka G). CCR2 wiąże na swojej powierzchni chemoatraktanty, między innymi białko MCP-1. Oddziaływanie chemoatraktantu z receptorem inicjuje proces chemotaksji, a więc przemieszczania się określonych komórek w kierunku zwiększonego gradientu. CCR2 ulega ekspresji w monocytach, komórkach hematopoetycznych szpiku oraz mezenchymalnych komórkach macierzystych.

W badaniu Ando i wsp. na myszach potwierdzono, że przeszczepione komórki macierzyste biorą udział w rekrutacji endogennych komórek macierzystych szpiku kostnego i formowaniu ognisk kostnienia przez odkładanie kostniny (ang. callus). Tworząca się w kostninie młoda kość gąbczasta stopniowo przebudowuje się w kość dojrzałą. Podstawą tego zjawiska jest oś MCP-1/CCR2 [25].

\section{Właściwości immunomodulacyjne komórek macierzystych}

Komórki macierzyste posiadają zdolność modulacji, poprzez wzmacnianie - immunostymulację lub osłabianie - immunosupresję, odpowiedzi układu odpornościowego organizmu. MSC przede wszystkim hamują proliferację limfocytów T, poprzez oddziaływanie transformującego czynnika wzrostu $\beta 1$ (ang. transforming growth factor $\beta 1$, TGF- $\beta 1$ ) oraz czynnika wzrostowego hepatocytów (ang. hepatocyte growth factor, HGF) in vitro. Zmniejszają wydzielanie cytokin IL-2, IFN- $\gamma$, TNF- $\alpha$, a zwiększają wytwarzanie IL-4.

Komórki macierzyste zatrzymują limfocyty T w fazie G0-G1 i hamują ekspresję cykliny D2, białka regulującego długość poszczególnych faz cyklu komórkowego [26]. MSC wydzielają indolamino-2,3-dioksygenazę (IDO), związek chemiczny odpowiedzialny za degradację tryptofanu, którego stężenie koreluje negatywnie z poziomem cytokin prozapalnych oraz pozytywnych białek ostrej fazy (CRP). Indukcja IDO nieodzownie wiąże się także z powstawaniem katabolitu tryptofanu-kinureniny, co prowadzi w konsekwencji do inhibicji proliferacji limfocytów T. Tlenek azotu wytwarzany przez komórki macierzyste hamuje fosforylację białka STAT-5 (ang. signal transducers and activators of transcription-5), należącego do grupy białek biorących udział $w$ przekazywaniu informacji $z$ powierzchni komórek do jądra oraz w aktywacji transkrypcji genów. Zwiększona ekspresja ludzkiego antygenu leukocytarnego G5 (ang. human leukocyte antygen-G5, HLA-G5) na powierzchni komórek macierzystych wydaje się istotnym mechanizmem upośledzającym odporność komórkową poprzez zmniejszenie aktywności limfocytów cytotoksycz- nych oraz komórek NK, a także poprzez zahamowanie proliferacji limfocytów $\mathrm{T} \mathrm{CD} 4^{+}$oraz indukcję ich różnicowania $w$ kierunku limfocytów $T$ regulatorowych. Wszystkie te mechanizmy wywołująź stan immunosupresji i w konsekwencji prowadzą do wytworzenia tolerancji immunologicznej. Badania części autorów wykazały również, że MSC są zdolne do hamowania komórek układu odpornościowego na drodze bezpośredniego kontaktu komórki z komórką.

Interakcje zachodzące pomiędzy komórkami macierzystymi a limfocytami B nie są w pełni poznane, mechanizmy oddziaływania są jednak stopniowo wyjaśniane. MSC blokują aktywność prozapalnego i prozakrzepowego układu receptor CD40 - ligand CD40 za pomocą przeciwciała monoklonalnego anty-CD40L. Hamują także produkcje przeciwciał i receptorów chemokinowych CXCR4, CXCR5 oraz CXCR7.

MSC wpływają na aktywność limfocytów T pomocniczych CD4 (ang. T helper, Th) poprzez stymulację komórek $\mathrm{T}$ regulatorowych (Treg) do proliferacji oraz supresję komórek Th17, które także stanowią subpopulację limfocytów T pomocniczych. Czynnik transkrypcyjny Foxp3 pełni ważną rolę w powstaniu i różnicowaniu limfocytów regulatorowych T (Treg). Liczne badania wykazały zwiększoną ekspresję Foxp3 w limfocytach $T$ $\mathrm{CD} 4{ }^{+} \mathrm{CD}_{25} 5^{+}$pod wpływem działania mezenchymalnych komórek macierzystych.

Charakterystyczną cechą limfocytów Th17 jest wydzielanie interleukiny 17 (IL-17A), stąd też wywodzi się ich nazwa. IL-17 odgrywa istotną rolę w patogenezie chorób autoimmunologicznych, zapalnych i alergicznych. Jak dotąd nie określono jednoznacznie pozytywnego bądź negatywnego wpływu tych komórek na rozwój nowotworów. W badaniu in vitro MSC hamują różnicowanie limfocytów T CD4+ w kierunku komórek Th17, a także hamują produkcję IL-17, IL-22, IFN- $\gamma$ i TNF- $\alpha$ przez w pełni zróżnicowane komórki Th17.

MSC zwiększają ilość Treg w osoczu pośrednio, poprzez oddziaływanie czynników produkowanych przez te komórki, takie jak IDO, PGE ${ }_{2}$, TGFb1, ale także poprzez bezpośredni kontakt komórki z komórką. Szczegółowe mechanizmy modulowania układu immunologicznego poprzez wywieranie wpływu na Treg i Th17 pozostają w dalszym ciągu przedmiotem badań.

\section{Podsumowanie}

Komórki macierzyste to niedojrzałe, prymitywne i niewyspecjalizowane komórki, posiadające zdolność do proliferacji, samoodnowy oraz do różnicowania się w bardziej wyspecjalizowane komórki potomne. Ich obecność wykazano w wie- 
lu tkankach i narządach, w tym także w układzie stomatognatycznym. Jama ustna wydaje się być wyjątkowo atrakcyjnym miejscem pozyskiwania komórek macierzystych. Powszechne występowanie i łatwa dostępność tych komórek w tkankach zębowych i okołozębowych sprawiają, że istnieje realna szansa ich zastosowania w celach terapeutycznych, a ich wykorzystanie rozwiązuje konflikty natury moralnej i etycznej.

Odbudowa struktury tkanki kostnej oraz przywrócenie jej funkcji podporowej i odżywczej zależy od umiejętnego wykorzystania komórek macierzystych i innych technik z zakresu inżynierii tkankowej. Regeneracja kości w jej klasycznym ujęciu zakłada użycie komórek tworzących kość, np. komórek macierzystych. Konieczne staje się także stworzenie rusztowania, które stanowić będzie podporę dla formowanej tkanki kostnej, oraz dostarczenie do organizmu wraz z macierzą i komórkami kościotwórczymi cząsteczek pobudzających komórki do różnicowania i tworzenia nowej kości.

Jedną z możliwości wykorzystania potencjału regeneracyjnego komórek macierzystych w obszarze jamy ustnej jest odbudowa wyrostków zębodołowych szczęki i żuchwy. Wyrostek zębodołowy stanowi podporę dla zębów naturalnych lub uzupełnień protetycznych i zanika już z chwilą utraty pojedynczego zęba. Utrata masy kostnej utrudnia podjęcie skutecznego leczenia stomatologicznego i ogranicza szanse uzyskania pozytywnych, długofalowych efektów terapeutycznych. Nowoczesna i innowacyjna metoda leczenia z zastosowaniem komórek macierzystych stwarza niebywałą szansę osiągnięcia spektakularnych efektów u pacjentów, u których dotychczas stosowane rutynowe postępowanie nie dawało satysfakcjonujących rezultatów.

\section{Oświadczenia}

\section{Oświadczenie dotyczące konfliktu interesów}

Autorzy deklarują brak konfliktu interesów w autorstwie oraz publikacji pracy.

\section{Źródła finansowania}

Autorzy deklarują brak źródeł finansowania.

\section{Piśmiennictwo}

[1] Aghaloo TL, Tuan RS, Schmitz JP, Aboud M, Amet E, Cardaropoli $\mathrm{G}$. The academy of osseointegration silver anniversary summit: impact of biological and technological advances on implant dentistry (stem cell therapy group report). Int J Oral Maxillofac Implants. 2011;26 (Suppl.):64-9.

[2] Schmelzeisen R, Schimming R, Sittinger M. Making bone: implant insertion into tissue-engineered bone for maxillary sinus floor augmentation-a preliminary report. $\mathrm{J}$ Cranio-Maxillo-fac Surg Off Publ Eur Assoc Cranio-Maxillo-fac Surg. 2003 Feb;31(1):34-9.

[3] Schimming R, Schmelzeisen R. Tissue-engineered bone for maxillary sinus augmentation. J Oral Maxil- lofac Surg Off J Am Assoc Oral Maxillofac Surg. 2004 Jun;62(6):724-9.

[4] Yamada Y, Ueda M, Hibi H, Nagasaka T. Translational research for injectable tissue-engineered bone regeneration using mesenchymal stem cells and platelet-rich plasma: from basic research to clinical case study. Cell Transplant. 2004;13(4):343-55.

[5] Yamada Y, Ueda M, Hibi H, Baba S. A novel approach to periodontal tissue regeneration with mesenchymal stem cells and platelet-rich plasma using tissue engineering technology: A clinical case report. Int J Periodontics Restorative Dent. 2006 Aug;26(4):363-9.

[6] Meijer GJ, de Bruijn JD, Koole R, van Blitterswijk CA. Cell based bone tissue engineering in jaw defects. Biomaterials. $2008 \mathrm{Jul} ; 29(21): 3053-61$.

[7] d'Aquino R, De Rosa A, Lanza V, Tirino V, Laino L, Graziano $A$, et al. Human mandible bone defect repair by the grafting of dental pulp stem/progenitor cells and collagen sponge biocomplexes. Eur Cell Mater. 2009 Nov 12;18:75-83.

[8] Kaigler D, Pagni G, Park CH, Braun TM, Holman LA, Yi E, et al. Stem cell therapy for craniofacial bone regeneration: a randomized, controlled feasibility trial. Cell Transplant. 2013;22(5):767-77.

[9] Caplan Al. Mesenchymal stem cells. J Orthop Res Off Publ Orthop Res Soc. 1991 Sep;9(5):641-50.

[10] Rickert D, Sauerbier S, Nagursky H, Menne D, Vissink A, Raghoebar GM. Maxillary sinus floor elevation with bovine bone mineral combined with either autogenous bone or autogenous stem cells: a prospective randomized clinical trial. Clin Oral Implants Res. 2011 Mar;22(3):251-8.

[11] Sauerbier S, Rickert D, Gutwald R, Nagursky H, Oshima $\mathrm{T}$, Xavier SP, et al. Bone marrow concentrate and bovine bone mineral for sinus floor augmentation: a controlled, randomized, single-blinded clinical and histological trial-per-protocol analysis. Tissue Eng Part A. 2011 Sep;17(17 -18):2187-97.

[12] Meijer GJ, de Bruijn JD, Koole R, van Blitterswijk CA. Cell-based bone tissue engineering. PLoS Med. 2007 Feb;4(2):e9.

[13] Zimmermann CE, Gierloff M, Hedderich J, Açil Y, Wiltfang $\mathrm{J}$, Terheyden $\mathrm{H}$. Survival of transplanted rat bone marrow-derived osteogenic stem cells in vivo. Tissue Eng Part A. 2011 Apr;17(7-8):1147-56.

[14] Boukhechba F, Balaguer T, Bouvet-Gerbettaz S, Michiels J-F, Bouler J-M, Carle GF, et al. Fate of bone marrow stromal cells in a syngenic model of bone formation. Tissue Eng Part A. 2011 Sep;17(17-18):2267-78.

[15] Quintavalla J, Uziel-Fusi S, Yin J, Boehnlein E, Pastor G, Blancuzzi V, et al. Fluorescently labeled mesenchymal stem cells (MSCs) maintain multilineage potential and can be detected following implantation into articular cartilage defects. Biomaterials. 2002 Jan;23(1):109-19.

[16] Quarto R, Mastrogiacomo M, Cancedda R, Kutepov SM, Mukhachev V, Lavroukov A, et al. Repair of large bone defects with the use of autologous bone marrow stromal cells. N Engl J Med. 2001 Feb 1;344(5):385-6.

[17] Kitoh $H$, Kitakoji T, Tsuchiya $H$, Katoh M, Ishiguro $N$. Transplantation of culture expanded bone marrow cells and platelet rich plasma in distraction osteogenesis of the long bones. Bone. 2007 Feb;40(2):522-8.

[18] Nagata M, Hoshina H, Li M, Arasawa M, Uematsu K, Ogawa $\mathrm{S}$, et al. A clinical study of alveolar bone tissue engineering with cultured autogenous periosteal cells: coordinated activation of bone formation and resorption. Bone. 2012 May;50(5):1123-9.

[19] Ohgushi H, Goldberg VM, Caplan Al. Repair of bone defects with marrow cells and porous ceramic. Experiments in rats. Acta Orthop Scand. 1989 Jun;60(3):334-9.

[20] Bruder SP, Kurth AA, Shea M, Hayes WC, Jaiswal N, Kadiyala $\mathrm{S}$. Bone regeneration by implantation of purified, culture-expanded human mesenchymal stem cells. J Orthop Res Off Publ Orthop Res Soc. 1998 Mar;16(2):155-62.

[21] Kon E, Muraglia A, Corsi A, Bianco P, Marcacci M, Martin I, et al. Autologous bone marrow stromal cells loaded 
onto porous hydroxyapatite ceramic accelerate bone repair in critical-size defects of sheep long bones. J Biomed Mater Res. 2000 Mar 5;49(3):328-37.

[22] Kawamoto A, Gwon HC, Iwaguro H, Yamaguchi JI, Uchida $\mathrm{S}$, Masuda $\mathrm{H}$, et al. Therapeutic potential of ex vivo expanded endothelial progenitor cells for myocardial ischemia. Circulation. 2001 Feb 6;103(5):634-7.

[23] Baggiolini M. Chemokines and leukocyte traffic. Nature. 1998 Apr 9;392(6676):565-8.

[24] Tashiro K, Tada H, Heilker R, Shirozu M, Nakano T, Honjo T. Signal sequence trap: a cloning strategy for secreted proteins and type I membrane proteins. Science. $1993 \mathrm{Jul}$ 30;261(5121):600-3.

[25] Ando Y, Matsubara K, Ishikawa J, Fujio M, Shohara R, Hibi $\mathrm{H}$, et al. Stem cell-conditioned medium accelerates distraction osteogenesis through multiple regenerative mechanisms. Bone. 2014 Apr;61:82-90.
[26] Glennie S, Soeiro I, Dyson PJ, Lam EW-F, Dazzi F. Bone marrow mesenchymal stem cells induce division arrest anergy of activated T cells. Blood. $2005 \mathrm{Apr}$ 1;105(7):2821-7.

Zaakceptowano do edycji: 2016-09-12 Zaakceptowano do publikacji: 2016-11-22

\section{Adres do korespondencji:}

Rafał Brożek

Collegium Stomatologicum UMP

ul. Bukowska 70, 60-812 Poznań

tel.: +48 618547078

e-mail: broz@ump.edu.pl 